specialists, it is our job to find out (a) how that mutual understanding is created notwithstanding all the observable differences and (b) how the differences we observe can best be made to serve the purposes of the business community.

A term that I will personally remember as having been launched in this conference is "interspecialism," as used by Priscilla Rogers. The term captures the essence of what business communication is. Interspecialism scems to link up the two sides of the duality: business communicators communicate as specialists in their own fields-with all the cultural and other differences that that implies - yet producing constructs that transcend these differences.

The key question in all this seems to be: "How do communicators make sense of a multilingual and multicultural business environment?" We now have one year-until the second ABC European Convention, in Antwerp in 2000-to think about that question. Instead of a specific answer-or answers-we will no doubt be coming up with further questions. But that, I think, just puts us in line with all the good conferences: they tend to raise more questions than they answer.

\title{
Internationalism, Technological Innovation, and New Associations: Bringing Change to Business Communication Research and Teaching
}

\section{Priscilla S. Rogers}

University of Michigan, Ann Arbor

AT THE START OF THE 1999 ABC European Convention in Helsinki, Finland, Professor Jan Ulijn raised the question "What may Europe contribute to international innovation in business communication?" With well over half the conference attendees 
from Europe, this conference provided many specific answers to that question-e.g. new perspectives on language, debate regarding International Business English, and new modes of collabordtion, the European Union being one dramatic model. The conference also raised questions regarding innovation in business communication research and teaching as well as in the way we function as an association of scholars and teachers. Several of these questions are considered here.

Is there any topic in business communication tcaching or research that is not in some way international? Is any teaching unit in business communication fully developed if its focus is solely domestic? Can a business communication research topic be considered significant if it has no relevance to the global competitive environment in which businesses operate? Can a literature review be truly complete if it does not include scholarship worldwide? Such questions recall the "Buy American" campaign that strong autumotive labor unions mounted some years back near my home, namely the Detroit Metropolitan area of Southern Michigan in the United States. Of course, unions intended that this campaign would activate US citizens to buy cars, trucks, and recreational vehicles from so-called US companies such as General Motors, Ford Motor Company, and Chrysler. But, in retrospect, the campaign was silly: Chrysler is now Daimler/Chrysler, a German-US company that, like General Motors and Ford, buys and produces vehicles all over the globe. As Thomas, Pollock, and Gorman recently observed, "products today may be designed in one country, fabricated in a second, assembled in a third, and sold throughout the world" (1999, p. 70). Indeed, even small local and regional companies are impacted by the global market economya regional box company in Dayton, Ohio, may obtain paper products, paints and glues, and printing presses from suppliers worklwide; moreover, their competition may just as easily come from a company in another country as a company across town. "Buy American" is clearly a thing of the past.

If the presentations at the $1999 \mathrm{ABC}$ European Convention are any measure, then we could safely say that business communica- 
tion research and teaching are not suffering from a "Buy American" myopia. For example, Nigel Reeves reminded us that globalization brings a need for new research instruments, such as the analytical system he called "linguistic auditing," which treats communication as a corporate system; Carson Varner explicated the increasing complexity of business agreements via e-mail, phone, fax, and face-to-face discussion given legal variations country-tocountry; and Hiromitsu Hayashida, Toshihiko Miura, and Shunitsu Nakasko used survey data from Japanese subsidiaries in Singapore and Malaysia to show ways the communication problems businesses face today differ from those in a less global marketplace.

Yet it does not hurt to consider how completely our business communication teaching and research reflect the global business environment. Do our class writing and speaking activities prompt students to consider content development, organizational approaches, business grammar, and issues of visualization from a global perspective in which various cultural interpretations come into play? Do our cases adequately represent the challenges of cross-cultural and cross-border exchange that our students can cxpect to face at work? And, to what extent do our research questions address the new globalism? Indeed, do our literature reviews incorporate discoveries by scholars worldwide-is it possible to have a complete list of references, for example, that does not include publications in two or more languages?

Is there any teaching or research in business communication that is not influenced in some way by technology? Speaking on the role of communications in corporate strategy, one of the 1999 ABC European Regional keynote speakers, Kaisa Vikkula, Vice President of Communications and Investor Relations at Partek, Finland, stated emphatically: "The Internet revolutionizes communication!" As Stepanek recently wrote in a special E.BIZ section of Business Week:

Gone are the days of the geographically captive customer, when merchants had the advantage of being the only store within driving distance. On the Web, the next shop is seconds away. Whar's more, it's open 24 hours (p. EB 30). 
Indeed, it goes without saying that e-commerce is a reality and growing fast, distance technologies facilitate "face-to-face" meetings, faxing is standard practice, and e-mail is an increasing part of day-to-day business interaction in most places in the world. Not surprisingly, then, the $\mathrm{ABC}$ European Convention included presentations such as Rigmore Aminne's demonstration of a CDROM multimedia program for self-study of business German; Christine Grosse and William King's description of a business communication course linking students in Phoenix, Arizona, with those in Monterrey, Mexico, using distance media and the Internet; Marc Blasband, Marinel Gerritsen, and Twan Laan's study of the effectiveness of the Internet and a "speaking computer" to provide information on public transportation; and Marjo Hevonoja and Hanna-Mari Rapo's report on how Web technologies are being used for corporate communications.

At other sessions presenters were asked to comment on technological issues: "Is PowerPoint commonly used, and, if so, are any problems associated with its use?" one attendee inquired of B.A. Andeweg, J.C. de Jong, K.M. van Oyen, and C. Wehrmann, who surveyed 4000 Dutch engineers regarding the type, timing, and nature of their presentations. "Are many presentations viewed via distance technologies?" asked another. After Marja-Liisa Kuronen's studied comparison of the verbal and non-verbal means Swedish and Finnish insurance companies use to describe their policies in customer brochures, she was asked "Do you anticipate that these communications will be distributed online in the near future, and what difference, if any, do you think this will make in the nature of these communications?" Titled "To what Extent is an Insurance Policy a Text that Interacts with a Customer?" Kuronen's research clearly invites questions regarding interactive technologies. All this punctuates the question: Dare any conference presentation, classroom exercise, or research paper in business communication exclude some mention, if not elaboration, regarding the impact of communication technology?

What does this first $\mathrm{ABC}$ meeting in Europe mean for the Association? Not too long ago, the idea of "internationalizing" the 
$A B C$ was just that, an idea. Now, having had several regionals outside the United States, including the first ABC European Convention, it's safe to say that $A B C$ members worldwide are successfully congregating. In fact, the experimental Webcasting of two sessions of the Helsinki meeting, facilitated by Maija Tammelin, is a sign that new technologies in the hands of members with considerable ingenuity may dramatically increase the number and means by which we meet. ABC journal editors have taken steps to include scholars from around the world on their editorial boards. ABC committees and the Board of Directors are internationally diverse as well. While more can be done, the $A B C$ membership has been internationalized and $A B C$ members from around the world are mecting regularly.

Yet associating, as our name applies, requires more than simply congregating. Associating requires continued discussion of our differences, differences in how we communicate, in what we regard as legitimate research, in the structure of our programs and departments, in the content we deem important for instruction, in the way we coordinate our other professional interests with those of $\mathrm{ABC}$, and more. Is business communication taught differently, for example, when it resides in a department that also offers courses in 11 or more foreign languages, as is the case at the Helsinki School of Economics and Business Administration? Is it professionally acceptable to submit an article to an $A B C$ journal which has already been published by a university press and distributed regionally (like a conference proceedings)?

It's already clear that exploring these differences will require some patience and generosity toward each other. We need to inform each other regarding cultural incorrectness and inquire of each other, digging deep till our differing perspectives and insights emerge. Finland is a kind of example. The German pliywright, Bertolt Brecht, is credited with saying that in Finland people are silent in two languages. Today Brecht's observation is clearly dated. As those attending the 1999 ABC European Convention observed, Helsinki enjoys the influence of many cultures and many languages, while Finland's strong voice in the European 
Union, international business savvy, and technological leadership (Nokia being a prime example) dramatically illustrate that the "silence" Brecht observed has been replaced with a kind of global activism. Is the Association for Business Communication going to be as successful?

\section{References}

ABC European Convention Programme (May, 1999). "Business through language and communication." Helsinki School of Econonics and Business , Administration, Helsinki, Finland.

Stepanek, M. (1999, March 22). You'll wanna hold their hands. Business Week E.Biz, pp. 30.31.

Thomas, H., Pollock, T., \& Gorman, P. (1999). Global strategic analyses: Frameworks and approaches. Academy of Management Executive, 13(1).

\section{The Convention: A Personal View}

\section{Anna Trosborg}

The Aarhus School of Business, Denmark

HAVING ARRIVED AT THE ABC European Convention in Helsinki, 20-22 May 1999, I was overwhelmed by the whole arrangement and the many interesting people and papers appearing in the programme. There were five plenary talks and six parallel tracks, all hosted by Tuija Nikko and Hilkka Yli-Jokipii within an excellent arrangement at the Helsinki School of Economics. This did not make my task as a commentator at the closing session an easy one. How should I set about it? It was impossible to do justice to everybody and everything. Discussing this problem with some of the conference participants, it was suggested to me that I should look at the arrangement as the table we were sitting around, happily chatting over a drink. After second thoughts I bought the idea.

We were actually sitting in a bar at a round table with three iron legs planted solidly on the ground. This seemed a fair image of the European Region of the Association for Business Commu- 